Reprod. Nutr. Dévelop., 1984, 24 (6), 927-935.

\title{
Autoradiographic investigation of sperm transit through the male mouse genital tract after tritiated thymidine incorporation
}

\author{
J.-P. DADOUNE, Marie-Françoise ALFONSI
}

Laboratoire d'Histologie-Embryologie-Cytogénétique

Faculté de Médecine Broussais-Hôtel-Dieu and U.E.R. Biomédicale des Saints-Pères 45, rue des Saint-Pères, 75270 Paris Cedex 06, France

Summary. The transit of spermatozoa in the genital tract of the male mouse was investigated by quantitative light microscopic autoradiography after intraperitoneal injection of tritiated thymidine. Transit duration in the caput and the corpus of the epididymis was shown to be 3 days; the total duration of transit in the genital tract was 5 days. These findings indicate that the time required for the transit of spermatozoa in the epididymal caput and corpus was comparable to that calculated in other mammals studied. However, the duration of sperm storage in the epididymal cauda appeared to be shorter than that previously reported for rodents.

\section{Introduction.}

The transit of spermatozoa in the male genital tract of numerous species has been studied by a variety of methods, using colored particles (Grant, 1958), radioopaque substances (McMillan and Harrisson, 1965), or isotopic labeling of the germ cells. The latter technique includes labeling either the DNA with ${ }^{32} \mathrm{P}$ or thymidine ${ }^{3} \mathrm{H}$, or the sperm-specific basic nucleoproteins with arginine ${ }^{14} \mathrm{C}$ (for review see Keneklis, 1975). The progression of labeled spermatozoa along the epididymal duct can be traced by quantitative assessment of the amount of radioactivity using liquid scintillation counting or autoradiography.

The duration of sperm transit in the male genital tract corresponds to the interval between the moment the labeled spermatozoa first appear in the caput of the epididymis and the time they appear in the ejaculate (Esnault et al., 1974). This transit has been calculated in humans, monkeys and in several species of domestic animals (for references see Courot, 1981) as well as in such rodents as rabbits (Amann et al., 1976 ; Orgebin-Crist, 1965), hamsters (Amann et al., 1976), rats (Robb et al., 1978) and guinea-pigs (Frenkel et al., 1973). As an extension to these findings, the aim of the present work was to investigate the transit of spermatozoa in the genital tract of the male mouse after the injection of tritiated thymidine. 


\section{Material and methods}

Forty-two male mice aged three months and weighing approximately $30 \mathrm{~g}$ each received an intraperitoneal injection $\left(7.410^{4} \mathrm{~Bq} / \mathrm{g}\right.$ body weight) of thymidine methyl- ${ }^{3} \mathrm{H}$ (CEA, Département des Radioéléments, Gif-sur-Yvette, France ; spc. Act $103.610^{10} \mathrm{~Bq} / \mathrm{mMol}$ ) in a sterile isotonic solution.

Collection and preparation of epididyma/ spermatozoa. - In the first group of 20 mice, one was killed each day between the 23rd and 37th day after tracer injection and subsequently at days 40,42, 45, 50 and 70 after the injection. Both epididymal ducts were removed and, after preliminary ligation, were cut into three parts, the caput, the corpus and the cauda (fig. 1). Each portion of the right epididymis was minced in a $2-\mathrm{ml}$ solution of Hank's solution (ref. 72512, Institut Pasteur, Paris). The suspensions, conserved for one hour at $4{ }^{\circ} \mathrm{C}$, were freed of tissue debris and then centrifuged. After three washings in Hank's solution, the sperm pellets were smeared on slides, fixed in ether-alcohol for $10 \mathrm{~min}$ and airdried. As a control, each corresponding section of the left epididymis was fixed in Bouin's fluid and embedded in paraffin.

Collection and preparation of ejaculated spermatozoa. - Between the 22nd and 39th days after tracer injection, and subsequently at days 41, 44, 49 and 69

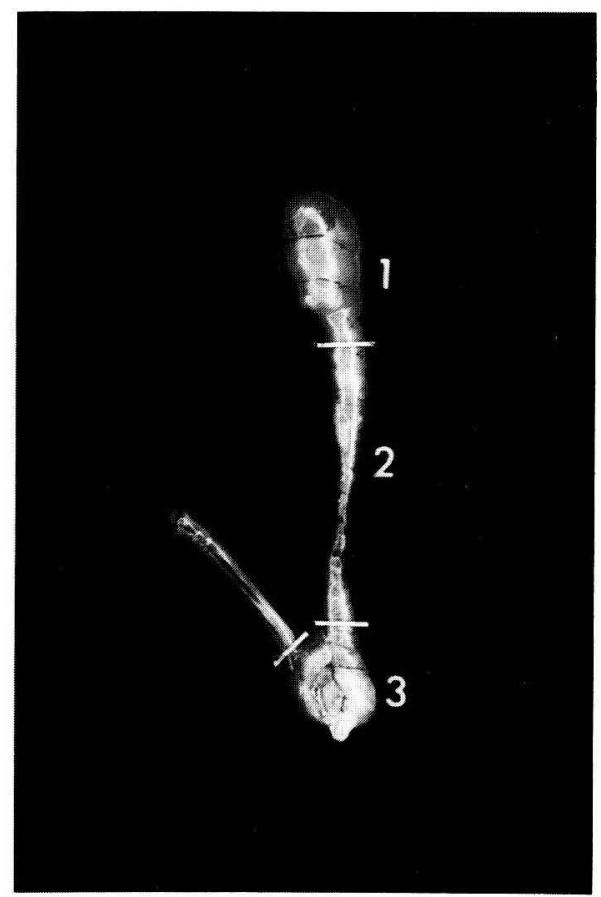

FIG. 1. - Different portions of the mouse epididymis from which the spermatozoa were collected. 1 : caput ; 2 : corpus ; 3 : cauda. 
afterwards, a different male in the second group of 22 mice, was mated each evening with five females in prooestrus. The next morning, the vaginal smears containing the spermatozoa were prepared and fixed as above.

Autoradiographic technique. - The smears and the paraffin sections were dipped in a $1: 2$ llford $\mathrm{K} 5$ nuclear emulsion (llford Ltd., Ilford, Essex, U.K.) and exposed at $4{ }^{\circ} \mathrm{C}$ for 56 days. The autoradiograms were developed in Kodak D 19B for 4 min at $18{ }^{\circ} \mathrm{C}$ and fixed in $30 \%$ sodium thiosulfate for $30 \mathrm{~min}$. The smears of the epididymal and ejaculated spermatozoa were stained for $1 \mathrm{~min}$ with a 0.01 solution of toluidine blue. The paraffin sections were examined unstained. Sperm cells with $\geq 3$ silver grains in the nucleus were considered to be labeled since less than $1.5 \%$ of the spermatozoa were associated with background clusters of 3 or more grains. The labeling index for each time interval was expressed by the percentage of labeled nuclei, for a sample of 300 labeled and unlabeled nuclei, with a confidence limit of 0.05 .

\section{Results.}

On the basis of previously established histological criteria (Soranzo et al., 1982), a comparison of the paraffin sections of the left epididymis with the sperm smears obtained from the corresponding right epididymal sections confirmed the localization of labeled sperm cells in the epididymal duct for a given time interval (Plate 1). Twenty-four days after isotope injection, the autoradiograms of the epididymal caput were entirely negative. On day 25 , the labeled spermatozoa had already reached the middle portion of the caput, whereas the lower segments of the epididymal duct were completely devoid of labeled cells. The latter appeared in the corpus at 26 days and in the cauda of the epididymis at 28 days.

The calculation of the labeling index of the smears showed that $32 \%$ of the spermatozoa were labeled in the caput at 25 days, $5 \%$ in the corpus at 26 days, $9 \%$ in the cauda at 28 days and $41 \%$ in the ejaculate at 30 days (fig. 2). Thus, the duration of transit from the caput to the cauda of the mouse epididymis was 3 days ; the total duration of transit in the male mouse genital tract was 5 days.

The analysis of variations in the labeling index as a function of time (fig. 2) revealed that the number of labeled spermatozoa increased regularly in the epididymal caput between days 25 and 29 after label injection. At day 29, about $90 \%$ of the cells labeled had a mean number of $18 \pm 1.2$ grains per nucleus. The range of labeling intensity was between 5 and 40 grains per cell, and $50 \%$ of the cells contained more than 18 grains. From 29 days, the labeling index diminished, but a new, significant peak, lower than the preceding one, occurred at days 32 to 33. At this time, the mean number of grains per cell was $6 \pm 0.7$, the range of labeling intensity ranged between 3 and 19 grains per cell, and $45 \%$ of the cells contained more than 6 grains.

Radioactivity followed the same pattern in the epididymal corpus. In the cauda, sperm labeling tended to become uniform over the course of time. However, two radioactive peaks of equal magnitude $170-72 \%$ of labeled cells) could still be detected at 34 and 37 days, respectively. 

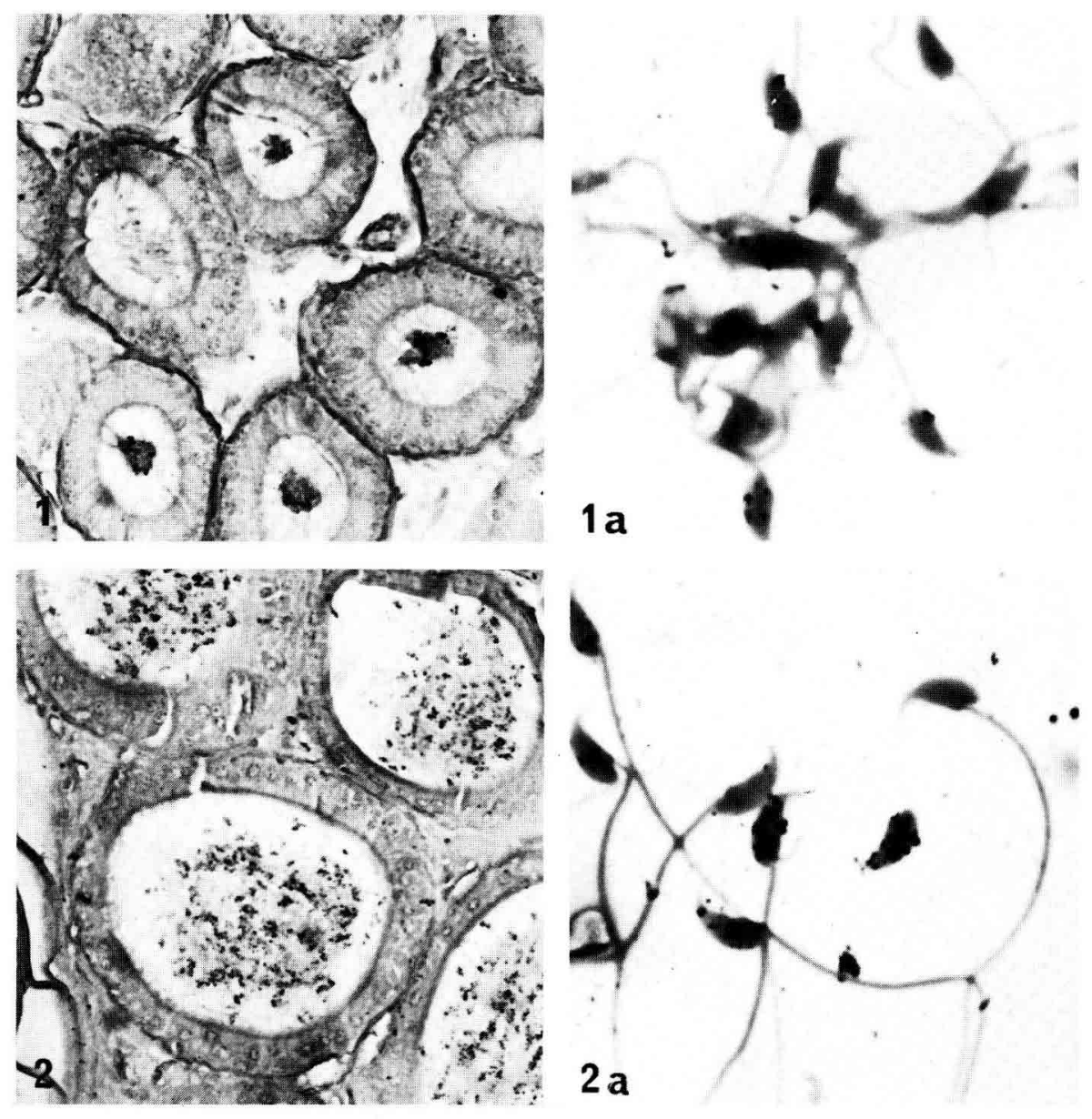

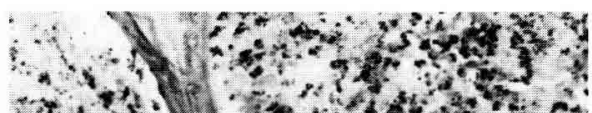

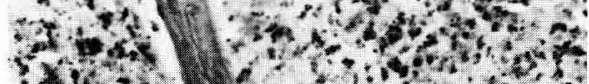

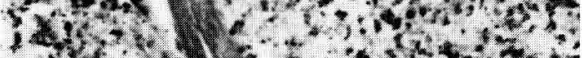

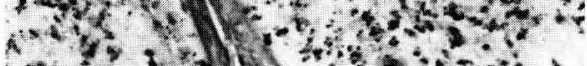
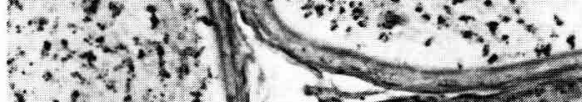
$y$ is $x^{2} x^{2} x^{2}$

?.

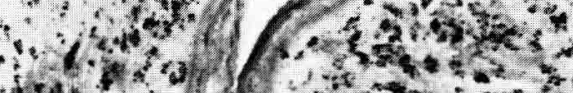

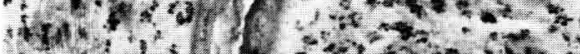

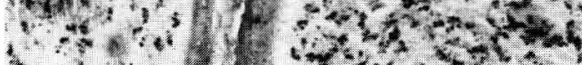

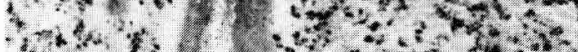

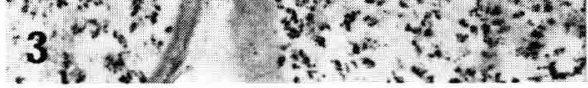

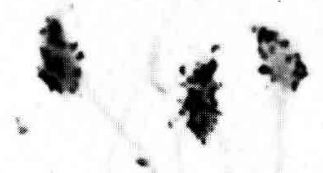

$3 \mathbf{a}$

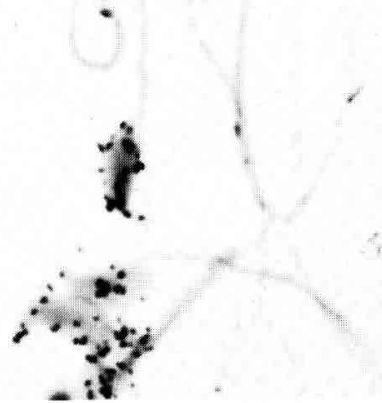

PLATE 1 : Autoradiographic visualization of the progression of labeled spermatozoa in the different segments of the mouse epididymis 40 days after tritiated thymidine injection. Unstained paraffin sections of the caput (fig. 1), corpus (fig. 2) and cauda (fig. 3) $(\times 340$ ) and smears of spermatozoa from the corresponding portions of the epididymis (figs. $1 \mathrm{a}-3 \mathrm{a})(\times 2,400)$. 

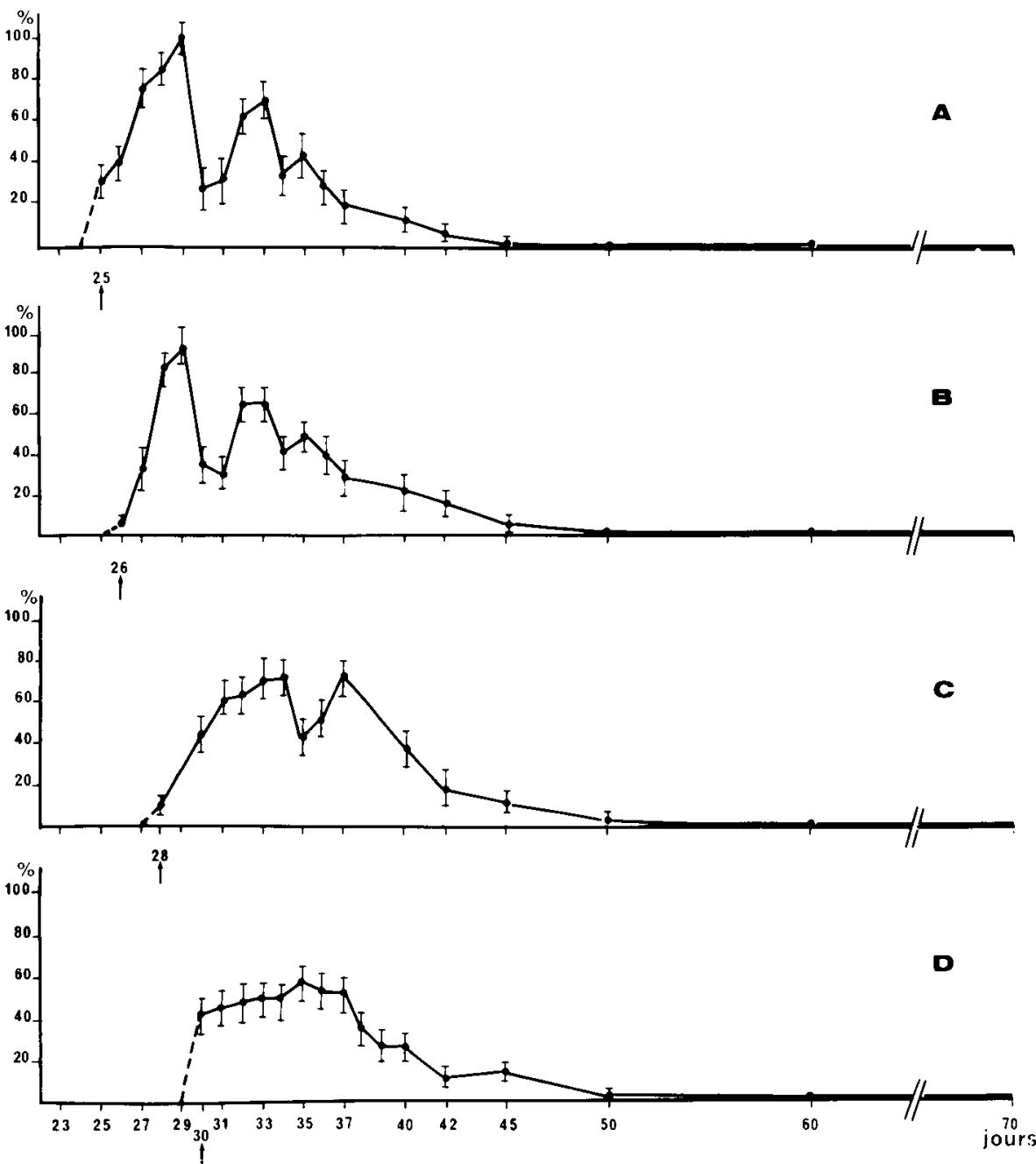

FIG. 2. - Abscissa : days after tritiated thymidine injection Ordinate : the percentage of labeled spermatozoa in the caput (A), corpus (B) and cauda (C) of the epididymis and in the ejaculate (D). Each dot represents the percentage of labeled nuclei ( $\geq 3$ grains) calculated for a total of 300 nuclei at a probability of $p=0.05$.

A relatively high number (approximately $40 \%$ ) of the first labeled sperm cells appeared in the ejaculate 30 days after injection of the precursor. The percentage of labeled cells then increased to attain about $58 \%$ by day 35 . This rate remained stable to day 37 . It then diminished to practically zero on day 50 .

\section{Discussion.}

It can be assumed that the first labeled sperm cells appearing in the caput of the epididymis came from the more mature germ cells which could incorporate 
tritiated thymidine. These cells are represented by preleptotene primary spermatocytes undergoing their last DNA synthesis prior to the long meiotic prophase (Clermont and Trott, 1969). Thus, the presence of labeled sperm cells in the epididymal caput at day 25 after the injection of tritiated thymidine shows that the total duration of meiosis and spermiogenesis is approximately 25 days in the mouse. A similar estimation $(26.5 \pm 0.5$ days $)$ has been put forward in an autoradiographic study on the mouse testis after intratesticular injection of tritiated thymidine (Ghosal and Mukherjee, 1971). Another type of analysis of spermatogenesis corroborates these findings: a study of tritiated leucine incorporation in the various components of mouse spermatozoa collected every other day over a period of 32 days from the caudal epididymis demonstrated that the total duration of protein synthesis during meiosis and spermiogenesis did not exceed 25 to 26 days (Bellvé, 1979).

However, preleptotene spermatocytes are not the only cells to incorporate the isotope at the moment of injection, since the spermatogonia are also labeled. After division, the latter cells are the source of labeled spermatozoa which are released into the lumen of the seminiferous tubules at specific intervals. According to data in mice concerning the mean duration of DNA synthesis in the different types of spermatogonia $\left(A_{1}, A_{2}, A_{3}, A_{4}\right.$, intermediary and $\left.B\right)$ and the mean duration of premeiotic DNA synthesis in primary spermatocytes (Monesi, 1962 ; Ghosal and Mukherjee, 1971), the duration of DNA synthesis in the germ cells, including the preleptotene stage, is of the order of 77 to $92 \mathrm{~h}$. Thus, the $96 \mathrm{~h}$ during which the number of labeled spermatozoa increase regularly in the epididymal caput (between days 25 and 29) appears to correspond to the length of time necessary for the production of the different generations of spermatozoa originating in the different types of spermatogonia labeled during the same seminal epithelial cycle.

Although the relationship of reserve stem cells to other varieties of $A$ spermatogonia is subject to controversy (Oakberg, 1971), stem cells having incorporated tritiated thymidine during a seminal epithelial cycle appear to be able to give rise to labeled cells in the following cycle. Furthermore, the duration of the seminal epithelial cycle is approximately 8 days in the mouse (Oakberg, 1956 ; Clermont and Trott, 1969). Consequently, the recrudescence of the number of labeled sperm cells in the epididymal caput between the $32 \mathrm{nd}$ and $33 \mathrm{rd}$ day after injection of tritiated thymidine (i. e. 7 to 8 days after the first labeled spermatozoa appear) seems to be attributable to the introduction of A1 spermatogonia (originating in the reserve stem cells labeled previously) into the next seminal epithelial cycle. The differences in the percentage of labeled cells and the intensity of labeling observed between the two successive waves of spermatozoa can be explained by the fact that the stem cells having incorporated the label, give rise to spermatozoa which are more weakly labeled, depending on the number of divisions they have yet to accomplish.

As concerns the period between tracer injection and the appearance of the labeled spermatozoa in each segment of the epididymis, the duration of transit for labeled spermatozoa in the caput and the epididymal corpus is 3 days, precisely the figure reported for mice (Meistrich, 1975) and Wistar rats (Amann et al., 
1976). Thus the time required for sperm maturation in the mouse epididymis is within the same range as that of several other mammals ( 2 to 5.5 days) which was calculated by dividing the number of spermatozoa present in each segment by the number of spermatozoa produced daily in the testis attached to that epididymis (Amann et al., 1976).

However, the displacement of the first peak of radioactivity along the epididymal duct shows that the duration of transit in the caput and the corpus is equal to 4 days, i. e. one day more than the time required for the shift of the labeled sperm front. This finding confirms that the spermatozoa do not cross the epididymal canal at the same speed, and that several generations of spermatozoa gradually tend to mix (Orgebin-Crist, 1965). This is most apparent in the cauda of the epididymis, which has been widely identified as a storage organ.

The time of appearance of labeled spermatozoa in the ejaculate, 30 days after tritiated thymidine incorporation, is in agreement with results given by Sirlin and Edwards (1958) on mice injected intraperitoneally with adenine ${ }^{14} \mathrm{C}$. The total duration of sperm transit in the genital tract of male mice is thus 5 days, including 2 days in the epididymal cauda and the vas deferens. However, the transit time in the epididymal cauda appears to be less than that calculated by Meistrich (1975) for the same species, which was between 5.6 and 5.8 days, depending on whether the calculation was based on the sperm reserves or on labeled sperm transit. The difference may be related to the fact that, in the study of Meistrich, the ejaculated spermatozoa were not collected from the animal population, in which case sperm transit time from the epididymal cauda to the vas deferens would correspond to the storage time of the gametes in the cauda. In the present work, on the contrary, the total transit time of spermatozoa in the male genital tract was calculated taking into account the moment the labeled cells first appeared in ejaculates collected from a different animal for each time interval, on and after 23 days. Therefore, it is likely that ejaculation leads to a reduction in the storage time of spermatozoa in the epididymal cauda. On the other hand, it should be noted that a wide range of epididymal transit times has been observed in rodents : 8 days for rats (Robb et al., 1978), 10 to 15 days for hamsters (Amann et al., 1976) and guinea-pigs (Frenkel et al., 1973) and 9 to 10 days for rabbits (Orgebin-Crist, 1965). These variations stem for the most part from the duration of sperm storage in the cauda.

The method of collection of the ejaculated spermatozoa used in this study may also explain the absence of waves of labeled spermatozoa habitually observed in frequently sampled animals (Amir and Ortavant, 1968). Similarly to what has been seen in rabbits after the incorporation of tritiated thymidine, the maximum percentage of labeled spermatozoa in mouse ejaculates was approximately $50-58 \%$. This percentage is notably less than the results of Sirlin and Edwards (1958) using the same species after the injection of adenine ${ }^{14} \mathrm{C}$. In the latter case, the percentage of labeled cells reached about a $90 \%$ maximum at 38 days. One reason for this disparity might be the type of label used. Adenine, which is catabolized much more slowly than thymidine, may be available for incorporation for several days after the injection (Sirlin, 1958). However, taking into consideration the high percentage of labeled spermatozoa found in the

Reproduction, Nutrition, Développement, $n^{\circ} 6,1984 .-9$ 
epididymal caput after thymidine incorporation (about $90 \%$ at 29 days), it may be supposed that the drop in the labeling index of ejaculated spermatozoa only reflected the progressive mixture of several generations of labeled and unlabeled cells during epididymal transit.

Reçu en février 1984.

Accepté en juillet 1984.

Résumé. Etude autoradiographique du transit des spermatozoïdes dans le tractus génital mâle de la souris après incorporation de thymidine tritiee.

Le transit des spermatozoïdes dans les voies génitales mâles de la souris a été étudié par autoradiographie quantitative après injection intrapéritonéale de thymidine tritiée. La durée du transit dans la tête et le corps de l'épididyme est de 3 jours. La durée totale du transit dans les voies génitales est de 5 jours. Ces données indiquent que le temps nécessaire au transit des spermatozoïdes dans la tête et le corps de l'épididyme est du même ordre de grandeur que celui calculé chez les différents mammifères étudiés. En revanche, la durée du stockage des spermatozoïdes dans la queue de l'épididyme est apparue plus courte que celle mentionnée antérieurement pour divers rongeurs.

\section{References}

AMANN R. P., JOHNSON L., THOMPSON D. L., PICKETT B. W., 1976. Daily spermatozoal production, epididymal spermatozoal reserves and transit time of spermatozoa through the epididymis of the rhesus monkey. Biol. Reprod., 15, 586-592.

AMIR D., ORTAVANT R., 1968. Influence de la fréquence des collectes sur la durée du transit des spermatozoïdes dans le canal épididymaire du bélier. Ann. Biol, anim. Biochim. Biophys., 8, 195-207.

BELLVÉ A. R., 1979. The molecular biology of mammalian spermatogenesis, 159-261. In FINN C. A., Oxford reviews of reproductive biology, Vol. 1, Clarendon Press Oxford.

CLERMONT Y., TROTT M., 1969. Duration of the cycle of the seminiferous epithelium in the mouse and hamster determined by means of ${ }^{3} \mathrm{H}$-thymidine and radioautography. Fert. Steril., 20, 805-817.

COUROT M., 1981. Transport and maturation of spermatozoa in the epididymis of mammals, 67-79. In BOLLACK C., CLAVERT A., HUBINONT P. O., Prog. Reprod. Biol. Epididymis and Fertility: Biology and Pathology. S. Karger, Basel, München, Paris, London, New York.

ESNAULT C., COUROT M., ORTAVANT R., 1974. Transport et maturation des spermatozoïdes épididymaires chez les animaux domestiques, 89-114. In HAFEZ E.S.E., THIBAULT C. G., Transport, survie et pouvoir fécondant des spermatozoïdes. Coll. INSERM, 4-7 nov. 1973, Nouzilly, France.

FRENKEL G., PETERSON R. N., FREUND M., 1973. Role of adenine nucleotide and the effect of caffein and dibutyryl cyclic AMP on the metabolism of guinea pig epididymal spermatozoa. Proc. Soc. exp. Biol. Med., 144, 420-425.

GHOSAL S. K., MUKHERJEE B. B., 1971. The chronology of DNA synthesis, meiosis and spermiogenesis in the male mouse and golden hamster. Can J. Genet. Cytol., 13, 672-682.

GRANT J. H., 1958. The passage of Trympan blue through the epididymis and its uptake by this organ. Proc. Soc. Study Fertil., 10, 95. 
KENEKLIS T. P., 1975. Radioisotope studies on gametogenesis. Bibliog. Reprod., 26, 593-600 and 713-720.

MCMILLAN E. W., HARRISON R. G., 1955. - The rate of passage of radiopaque medium along the ductus epididymis of the rat. Proc. Soc. Study Fert., 7, 35-40.

MEISTRICH M. L., 1975. Alteration of epididymal sperm transport and maturation in mice by oestrogen and testosterone. Nature, 258, 145-147.

MONESI V., 1962. Autoradiographic study of DNA synthesis and the cell cycle in spermatogonia and spermatocytes of mouse testis using tritiated thymidine. J. Cell Biol., 14, 1-18.

OAKBERG E. F., 1956. Duration of spermatogenesis in the mouse and timing of stages of the cycle of the seminiferous epithelium. Amer. J. Anat., 99, 507-516.

OAKBERG E. F., 1971. Spermatogonial stem-cell renewal in the mouse. Anat. Rec., 169, 515-532.

ORGEBIN-CRIST M. C., 1965. Passage of spermatozoa labelled with thymidine-3H through the ductus epididymis of the rabbit. J. Reprod. Fert., 10, 241-251.

ROBB G. W., AMANN R. P., KILLIAN G. J., 1978. Daily sperm production and epididymal sperm reserves of pubertal and adults rats. J. Reprod. Fert., 54, 103-107.

SIRLIN J. L., 1958. Labelling of mouse spermatozoa by adenine-8- ${ }^{14} \mathrm{C}$ and thymidine- ${ }^{3} \mathrm{H}$. Exp. Cell Res., 15, 250-253.

SIRLIN J. L., EDWARDS R. G., 1958. The labelling of mammalian spermatozoa with radioactive tracers. J. exp. Zool., 137, 363-388.

SORANZO L., DADOUNE J. P., FAIN-MAUREL M. A., 1982. La segmentation du canal épididymaire chez la souris : Etude ultrastructurale. Reprod. Nutr. Dévelop., 22, 999-1012. 